\title{
ОСВІТНЬО-НАУКОВА ПРОГРАМА ЗА СПЕЦІАЛЬНІСТЮ 224 «ТЕХНОЛОГІЇ МЕДИЧНОЇ ДІАГНОСТИКИ ТА ЛІКУВАННЯ»
}

\author{
О. П. Мінцер, Т. М. Бабкіна, О. В. Щербіна, \\ В. В. Краснов, Ю. А. Бісюк, Л. І. Сергієнко \\ Національний університет охорони здоров'я України імені П. Л. Шупика
}

\begin{abstract}
Представлено сучасний фрормат стратегії і програми навчання майбутніх спеціалістів ступеня доктора фрілософії за спеціальністю 224 «Технології медичної діагностики та лікування» галузі знань 22 «Охорона здоров'я». Методами експертного оцінювання проаналізовано розвиток теорії і практики застосування технологій діагностики та лікування захворювань внутрішніх органів, у тому числі інформаційних. Унісріковано сучасні технології клінічних лабораторних і променевих методів дослідження, що сприяють підвищенню якості надання медичної допомоги; методи променевої терапії, що сприяють підвищенню ефективності лікування онкологічних і неонкологічних захворювань, а також методи прийняття рішень у діагностиці, лікуванні та прогнозуванні станів пацієнта.

По завершенню навчання, здобувачі вищої освіти третього рівня мають оволодіти загальнонауковими компетентностями, здобути універсальні навики дослідника та мовні компетентності. Тематика курсів просресійної підготовки розроблена 3 метою сприяння здатності інтегрувати знання та розв'язувати складні завдання в мультидисциплінарних і трансдисциплінарних контекстах. Отже, зміст запропонованої освітньо-наукової програми за спеціальністю 224 «Технології медичної діагностики та лікування» направлено на підготовку висококваліфікованих і конкурентоспроможних спеціалістів ступеня доктора фрілософрії та здобуття ними в процесі навчання необхідних теоретичних знань, що носять мультидисциплінарний характер, та комплексу практичних умінь, навиків і компетентностей для виконання інноваційних наукових досліджень та впровадження отриманих результатів у практичну охорону здоров'я.
\end{abstract}

Ключові слова: освітньо-наукова програма, технології медичної діагностики та лікування, здобувач вищої освіти, компетентність, мульдисциплінарність, трансдисциплінарність.

\section{EDUCATIONAL-SCIENTIFIC PROGRAM BY SPECIALTY 224 «TECHNOLOGIES OF MEDICAL DIAGNOSIS AND TREATMENT»}

\author{
O. P. Mintser, T. M. Babkina, O. V. Shcherbina, \\ V. V. Krasnov, Yu. A. Bisyuk, L. I. Sergiienko \\ Shupyk National Healthcare University of Ukraine
}

Background. The modern format of the strategy and training program for future specialists of the degree of Doctor of Philosophy in the specialty 224 «Technologies of medical diagnostics and treatment» (according to the international classification 0914 «Medical diagnostic and treatment technology») of the branch of knowledge 22 «Health care» is presented.

Material and methods. The development of the theory and practice of application of technologies of diagnostics and treatment of diseases of internal organs, including informational ones is analyzed by methods of expert assessment. Unified modern technologies of clinical laboratory and radiological research methods that help improve the quality of care; methods of radiation therapy that increase the effectiveness of treatment of cancer and non-cancer diseases, as well as methods of decision-making in the diagnosis, treatment and prognosis of the patient's condition.

Results. Upon completion of their studies, third-level higher education students must master general scientific (philosophical) competencies, acquire universal research skills and language competencies. The topics of the training courses are designed to promote the ability to integrate knowledge and solve complex problems in multidisciplinary and transdisciplinary contexts.

Conclusion. The content of the proposed educational-scientific program in specialty 224 «Technologies of medical diagnostics and treatment» is aimed at training highly qualified and competitive specialists of the degree of Doctor of Philosophy, acquisition by them in the course of training of necessary theoretical knowledge and a complex of practical abilities, skills and competences to perform innovative research, also the implementation of the obtained results in practical health care.

Key words: educational-scientific program, technologies of medical diagnostics and treatment, higher education, competence, multidisciplinarity, transdisciplinarity. 


\title{
ОБРАЗОВАТЕЛЬНО-НАУЧНАЯ ПРОГРАММА ПО СПЕЦИАЛЬНОСТИ 224 «ТЕХНОЛОГИИ МЕДИЦИНСКОЙ ДИАГНОСТИКИ И ЛЕЧЕНИЯ»
}

\author{
О. П. Минцер, Т. М. Бабкина, О. В. Щербина, \\ В. В. Краснов, Ю. А. Бисюк, Л. И. Сергиенко \\ Национальный университет здравоохранения Украины имени П. Л. Шупика
}

\begin{abstract}
Представлено современный формат стратегии и программы обучения будущих специалистов степени доктора срилософии по специальности 224 «Технологии медицинской диагностики и лечения» отрасли знаний 22 «Здравоохранение». Методами экспертного оценивания проанализировано развитие теории и практики применения технологий диагностики и лечения заболеваний внутренних органов, в том числе инорормационных. Унифицированы современные технологии клинических лабораторных и лучевых методов исследования, способствующие повышению качества оказания медицинской помощи; методы лучевой терапии, способствующие повышению эфффективности лечения онкологических и неонкологических заболеваний, а также методы принятия решений в диагностике, лечении и прогнозировании состояний пациента.

По завершению обучения, соискатели высшего образования третьего уровня должны овладеть общенаучными компетентностями, получить универсальные навыки исследователя и языковые компетентности. Тематика курсов профессиональной подготовки разработана с целью содействия способности интегрировать знания и решать сложные задачи в мультидисциплинарных и трансдисциплинарных контекстах. Содержание предложенной образовательно-научной программы по специальности 224 «Технологии медицинской диагностики и лечения» направлено на подготовку высококвалифицированных и конкурентоспособных специалистов степени доктора фрилософии, получения ими в процессе обучения необходимых теоретических знаний, носящих мультидисциплинарный характер, и комплекса практических умений, навыков и компетентностей для выполнения инновационных научных исследований и внедрения полученных результатов в практическое здравоохранение.
\end{abstract}

Ключевые слова: образовательно-научная программа, технологии медицинской диагностики и лечения, соискатель высшего образования, компетентность, мультидисциплинарность, трансдисциплинарность.

Вступ. Рішення проблем підготовки висококваліфікованого, конкурентоспроможного, інтегрованого в європейський і світовий науково-освітній простір спеціаліста ступеня доктора філософії у галузі знань 22 «Охорона здоров’я» за спеціальністю 224 «Технології медичної діагностики та лікування» (відповідає міжнародній класифікації 0914 «Medical diagnostic and treatment technology»), здатного до самостійної науководослідницької, дослідницько-інноваційної, науково-організаційної, педагогічно-організаційної та практичної діяльності в галузі, а також викладацької роботи у закладах вищої освіти вимагають постійного вдосконалення. Тому проєктною групою Національного університету охорони здоров’я (НУОЗ) України імені П. Л. Шупика запропоновано в сучасному форматі стратегію та програму навчання майбутніх спеціалістів. Гарант освітньо-наукової програми та голова проєктної групи — професор О. П. Мінцер, завідувач кафедри медичної інформатики факультету підвищення кваліфікації викладачів.

\section{1. ПРОФІЛЬ ОСВІТНЬОЇ ПРОГРАМИ}

Галузь знань 22 «Охорона здоров'я»

Спеціальність 224 «Технології медичної діагностики та лікування»

\begin{tabular}{|l|l|}
\hline \multicolumn{2}{|c|}{1 - Загальна інформація } \\
\hline Тип освітньої програми & $\begin{array}{l}\text { Освітньо-наукова програма } \\
\text { третій (освітньо-науковий) рівень вищої освіти }\end{array}$ \\
\hline Обсяг освітньої програми & 60 кредитів ЄКТС (4 академічних роки) \\
\hline Ступінь вищої освіти & Доктор філософії \\
\hline
\end{tabular}




\begin{tabular}{|c|c|}
\hline $\begin{array}{l}\text { Офіційна назва } \\
\text { освітньої програми }\end{array}$ & Технології медичної діагностики та лікування \\
\hline $\begin{array}{l}\text { Повна назва закладу вищої освіти } \\
\text { та структурних підрозділів, } \\
\text { де здійснюється навчання }\end{array}$ & $\begin{array}{l}\text { Національний університет охорони здоров’я України } \\
\text { імені П. Л. Шупика, } \\
\text { Факультет підвищення кваліфікації викладачів }\end{array}$ \\
\hline Цикл/рівень & $\begin{array}{l}\text { HPK України - } 8 \text { рівень, FQ-EHЕA - третій цикл, EQF- } \\
\text { LLL - } 8 \text { рівень }\end{array}$ \\
\hline Мова викладання & українська \\
\hline Строк дії освітньої програми & 5 років \\
\hline Передумови & Ступінь магістра чи ОКР спеціаліста \\
\hline Форми навчання & очна (денна, вечірня), заочна \\
\hline $\begin{array}{l}\text { Інтернет-адреса } \\
\text { постійного розміщення опису } \\
\text { освітньої програми }\end{array}$ & https://nuozu.edu.ua/nv/vo/aspirantura-ta-doktorantura \\
\hline & 2 - Мета освітньої програми \\
\hline \multicolumn{2}{|c|}{$\begin{array}{l}\text { Підготовка висококваліфікованого, конкурентоспроможного, інтегрованого в європейський } \\
\text { і світовий науково-освітній простір спеціаліста ступеня доктора філософії у галузі знань } 22 \text { «Охорона } \\
\text { здоров’я» за спеціальністю } 224 \text { «Технології медичної діагностики та лікування», здатного до } \\
\text { самостійної науково-дослідницької, дослідницько-інноваційної, науково-організаційної, педагогічно- } \\
\text { організаційної та практичної діяльності в галузі, а також викладацької роботи в закладах вищої освіти. }\end{array}$} \\
\hline \multicolumn{2}{|c|}{3 - Характеристика освітньої програми } \\
\hline $\begin{array}{l}\text { Предметна область } \\
\text { (галузь знань / спеціальність / } \\
\text { спеціалізація (за наявності)) } \\
\end{array}$ & $\begin{array}{l}\text { Галузь знань: } 22 \text { «Охорона здоров’я» } \\
\text { Спеціальність: } 224 \text { «Технології медичної діагностики та лікування» }\end{array}$ \\
\hline Орієнтація освітньої програми & Освітньо-наукова програма, дослідницько-інноваційна \\
\hline $\begin{array}{l}\text { Основний фокус освітньої } \\
\text { програми та спеціалізації }\end{array}$ & $\begin{array}{l}\text { Розвиток теорії і практики застосування технологій діагностики } \\
\text { та лікування захворювань внутрішніх органів, у тому числі інфор- } \\
\text { маційних, з метою вдосконалення діагностики порушень струк- } \\
\text { тури, функції органів і систем, покращення здоров’я населення. } \\
\text { Впровадження сучасних технологій клінічних лабораторних і про- } \\
\text { меневих методів дослідження, що сприяють підвищенню якості } \\
\text { надання допомоги. Впровадження сучасних методів променевої } \\
\text { терапії, що сприяють підвищенню ефективності лікування онко- } \\
\text { логічних і неонкологічних захворювань. }\end{array}$ \\
\hline
\end{tabular}




\begin{tabular}{|c|c|}
\hline & $\begin{array}{l}\text { Теорія та методи прийняття рішень у діагностиці, лікуванні } \\
\text { та прогнозуванні станів пацієнта. Грід-технології. Систематизація } \\
\text { та структуризація медичної інформації. Створення сучасних } \\
\text { технологій, що сприяють збереженню та відновленню здоров’я. }\end{array}$ \\
\hline Особливості освітньої програми & $\begin{array}{l}\text { Реалізується у наукових групах, активних у широкому колі до- } \\
\text { сліджень, що ведуться в галузі охорони здоров’я, в тому числі } \\
\text { впровадження технологій раннього виявлення та профілактики } \\
\text { захворювань, створення онтологічних моделей. }\end{array}$ \\
\hline \multicolumn{2}{|c|}{4 - Придатність випускників до працевлаштування та подальшого навчання } \\
\hline $\begin{array}{l}\text { Придатність } \\
\text { до працевлаштування }\end{array}$ & $\begin{array}{l}\text { Робочі місця в закладах охорони здоров'я, науково-дослідних } \\
\text { установах, менеджмент та адміністрування в сфері охорони } \\
\text { здоров'я, викладання у закладах вищої освіти, самостійне пра- } \\
\text { цевлаштування. }\end{array}$ \\
\hline Подальше навчання & $\begin{array}{l}\text { Можлива подальша підготовка на четвертому (науковому) } \\
\text { рівні вищої освіти. }\end{array}$ \\
\hline \multicolumn{2}{|r|}{5 - Викладання та оцінювання } \\
\hline Викладання та навчання & $\begin{array}{l}\text { Гуманізація, що передбачає не лише вивчення дисциплін гума- } \\
\text { нітарного циклу, які наповнюють зміст освіти проблемами лю- } \\
\text { дини, а й духовно-особистісну спрямованість кожної навчальної } \\
\text { дисципліни, формування міжособистісних стосунків на основі } \\
\text { поваги до людини, довіри, доброти, чуйності, уваги, співчуття, } \\
\text { віри у позитивність її дій. } \\
\text { Аксіологічний підхід орієнтує на визначальну роль цінностей } \\
\text { у використанні людиною можливостей, що надає їй наявність } \\
\text { тих або інших явищ, процесів і обставин, зокрема, гуманістична } \\
\text { версія аксіології визначає пріоритет загальнолюдських цінностей } \\
\text { та самоцінність життя кожної людини; дозволяє вивчати явища } \\
\text { виходячи з усвідомлення цінності всього живого; дозволяє сфор- } \\
\text { мувати власну систему особистісних і професійних цінностей, } \\
\text { виходячи з урахування різноманіття релігійних, культурних } \\
\text { та етнічних особливостей усіх членів суспільства. } \\
\text { Особистісний підхід - вимагає визнання особистості як про- } \\
\text { дукту соціального розвитку, носія культури, її унікальності, } \\
\text { інтелектуальної і моральної свободи, права на повагу, що пе- } \\
\text { редбачає опору на природний процес саморозвитку здібностей, } \\
\text { самовизначення, самореалізацію, самоствердження, створення } \\
\text { для цього відповідних умов. } \\
\text { Діяльнісний підхід, спрямований на організацію діяльності } \\
\text { здобувача вищої освіти в якій він був би активним у пізнанні, } \\
\text { праці, спілкуванні, своєму розвитку. } \\
\text { Ресурсний підхід - ставить питання про організацію навчання, } \\
\text { орієнтованого на пошук і розвиток потенціальних можливостей } \\
\text { кожного здобувача вищої освіти. }\end{array}$ \\
\hline
\end{tabular}


Викладання та навчання

Оцінювання

Інтегральна компетентність (IK)

Загальні компетентності (3К)
Системний підхід - орієнтує на цілісне та послідовне дослідження явищ і процесів як сутнісно взаємопов'язаних, структурно організованих у стійку динамічну єдність, здатну самовідтворюватися в умовах зовнішніх викликів.

Синергетичний підхід, провідним принципом якого є самоорганізація та саморозвиток, що здійснюються на основі постійної активної взаємодії цих систем із зовнішнім середовищем і веде до змін, становлення нових якостей.

Компетентністний підхід передбачає аксіологічну, мотиваційну, рефлексивну, когнітивну, операційно-технологічну та інші складові результатів навчання, що відображують примноження не лише знань, умінь і навиків, а й досвіду емоційно-ціннісного ставлення.

На початку тісне наукове керівництво, підтримка наукового керівника, підтримка та консультування з боку колег із наукової групи. Вивчення наукової методології на основі різноманітних інтерактивних ресурсів, що пропонуються здобувачу вищої освіти. Лекційні курси, семінари, консультації, самопідготовка у бібліотеці та на основі інтелекту, індивідуальні консультації.

Різні форми проміжного та заключного контролю на етапах вивчення дисциплін освітньо-наукової програми (залік, есе, опитування, комп’ютерне тестування, захист самостійних проєктів і рефератів, контрольні роботи). Наукові публікації та виступи на наукових форумах. Наукові звіти з оцінюванням досягнутого. Моніторинг виконання індивідуального плану та академічної успішності на всіх рівнях (науковим керівником / керівниками, колективом кафедри, вченою радою факультету), атестація. Захист дисертаційної роботи відповідно до чинних нормативних вимог.

\section{6 - Програмні компетентності}

Здатність розв’язувати комплексні проблеми в області професійної медичної діяльності за спеціальністю технології медичної діагностики та лікування в галузі охорони здоров’я; проводити оригінальне наукове дослідження; інтегрувати отриманні данні та інформацію; будувати концептуальні, структурні та математичні моделі; здійснювати дослідницько-інноваційну діяльність у галузі охороні здоров’я на основі глибокого переосмислення наявних і створення нових цілісних теоретичних або практичних знань та/або професійної практики.

\section{3К1. Дослідницькі компетентності}

- Здатність до абстрактного мислення, синтезу, аналізу та оцінювання сучасних наукових досягнень, генерування нових знань при вирішенні дослідницьких і практичних завдань;

- $\quad$ Здатність до самостійного проведення наукового та патентного пошуку з використанням сучасних технологій контент-аналізу та колокейт-аналізу, створення власних баз даних; 
- Здатність до проведення наукового дослідження в природничих науках із урахуванням сучасних філософських знань, філософської антропології, філософії науки, біоетики, етики біомедичних досліджень;

- Здатність до оцінювання результатів наукових досліджень із використанням знань та вмінь в області медичної інформатики, поглибленого статистичного аналізу даних;

- Здатність застосовувати сучасні інформаційні технологій у науковій діяльності, організації та проведенні навчальних занять;

- Здатність до управління науковими проєктами, складання пропозицій про фінансування наукових досліджень, реєстрації прав інтелектуальної власності;

- Здатність до набуття універсальних навиків дослідника, зокрема усної та письмової презентації результатів власного наукового дослідження державною мовою з застосуванням сучасних світоглядних і філософських знань.

\section{K2. Мовні компетентності}

- Здатність представляти та обговорювати наукові результати, вести наукову дискусію державною та іноземною мовами в усній і письмовій формі, володіти науковою термінологію; - Здатність до повного розуміння іншомовних наукових текстів у галузі охорони здоров'я та вільного письмового викладення наукового тексту іноземною мовою.

\section{3К3. Комунікативні компетентності}

- Здатність ефективно застосовувати навики риторики, спілкуватися зі спеціальною та загальною аудиторіями державною та іноземною мовами;

- Здатність представляти складну інформацію в зручний і зрозумілий спосіб усно та письмово, використовуючи відповідну технічну лексику та методи;

- Готовність цінувати та поважати різноманітність та мультикультурність;

- Здатність до ведення наукової дискусії, спілкування з рецензентами, широкою академічною спільнотою та з суспільством у цілому в сфері їх компетентності.

\section{3К4. Робота в групових проєктах}

- Готовність брати участь у роботі українських і міжнародних дослідницьких колективів для вирішення наукових і науковоосвітніх завдань;

- Здатність працювати у великій науковій групі, розуміючи відповідальність за результати роботи, а також ураховуючи бюджетні витрати та персональні зобов'язання;

- Спроможність до наукового керівництва, управління проєктами, здатність викладати та передавати знання у наукових групах. 


\section{3К5. Управлінські компетентності}

- Готовність організувати роботу колективу в розв'язанні актуальних проблем технологій медичної діагностики та лікування;

- Здатність працювати в умовах обмеженого часу та ресурсів, а також мотивувати та управляти роботою інших для досягнення поставлених цілей.

\section{3К6. Загальнонаукові (філософські) компетентності}

- Здатність до абстрактного мислення, аналізу та синтезу;

- Здатність здійснювати критичний аналіз філософських та наукових засад теоретичної та практичної діяльності в природничих науках у контексті цінностей сучасної науки та загальнолюдських цінностей;

- Здатність засвоювати та розвивати філософську культуру мислення, світоглядні уявлення про загальнонаукові, філософські, соціокультурні засади гуманітарного та природничого знання;

- Здатність усвідомлювати рівні можливості та гендерні проблеми, розуміти сучасні ідеї філософії гендеру;

- Здатність застосовувати цінності та принципи біоетики під час планування та проведення наукових досліджень.

\section{3К7. Викладацькі компетентності}

- Здатність педагогічно мислити: діагностувати педагогічні явища, аналізувати їх складові, знаходити способи оптимального вирішення педагогічних проблем;

- Здатність до конкретизації педагогічного прогнозування в планах навчання та виховання, обгрунтування способів та етапів їх реалізації;

- Здатність до рефлексії (уміння аналізувати свою професійну діяльність);

- $\quad$ Здатність працювати в сучасних середовищах передавання знань (системах навчання) та застосовувати сучасні педагогічні системи навчання.

\section{ЗК8. Особистісні компетентності}

- Здатність планувати та вирішувати завдання власного професійного й особистісного розвитку;

- Здатність працювати автономно;

- Здатність бути критичним і самокритичним;

- Здатність генерувати нові ідеї та концепції (креативність), використовувати технології наукової творчості;

- Здатність до лідерства та розвитку лідерських якостей.

\section{3К9. Етичні зобов'язання}

- $\quad$ Здатність слідувати етико-правовим нормам та моральним цінностям, принципам етики та біоетики у професійній діяльності, під час планування та проведення наукових досліджень;

- Здатність слідувати принципам академічної доброчесності під час планування, проведення, аналізу та публікації результатів наукового дослідження; 


\begin{tabular}{|c|c|}
\hline & $\begin{array}{l}\text { - } \quad \text { Здатність здійснювати теоретичну та практичну діяльність } \\
\text { в області природничих наук на основі сучасної етики науки, } \\
\text { принципів і цінностей біоетики, етики біомедичних досліджень } \\
\text { та загальнолюдських цінностей; } \\
\text { - } \quad \text { Здатність діяти соціально відповідально та громадянсько } \\
\text { свідомо, прагнути до збереження навколишнього середовища. }\end{array}$ \\
\hline \multirow[t]{4}{*}{$\begin{array}{l}\text { Спеціальні (фахові, професійні) } \\
\text { компетентності (СК) }\end{array}$} & $\begin{array}{l}\text { Загальнопрофесійні компетентності } \\
\text { СК1. } \\
\text { - здатність виконувати оригінальні дослідження зі спеціальності } \\
\text { Технології медичної діагностики та лікування в галузі Охорона } \\
\text { здоров’я, досягати наукових результатів, що створюють нові } \\
\text { знання, зі звертанням особливої уваги на актуальні завдання/ } \\
\text { проблеми та застосування новітніх наукових методів; } \\
\text { - здатність критично аналізувати комплексні завдання, синтезу- } \\
\text { вати нові ідеї, зокрема в міждисциплінарних і трансдисциплі- } \\
\text { нарних сферах; розробляти та реалізовувати наукові проєкти } \\
\text { на основі системно інтегруючої функції медичної інформатики } \\
\text { для забезпечення глибокого переосмислення наявного та забез- } \\
\text { печення приросту нового системного знання та/або модернізації } \\
\text { професійної практики, розв’язання складних соціально значущих } \\
\text { питань; } \\
\text { - здатність планувати та організовувати проведення експери- } \\
\text { ментального та/або клінічного дослідження, обирати сучасні } \\
\text { методологічні підходи до оцінювання результатів; } \\
\text { - здатність аналізувати наукову літературу (вітчизняну та за- } \\
\text { рубіжну), застосовувати методи метааналізу для оброблення } \\
\text { наукових оглядів; } \\
\text { - здатність до застосування сучасних інформаційно-комунікацій- } \\
\text { них технологій у науковій і практичній діяльності; } \\
\text { - здатність аналізувати результати наукових досліджень та оформ- } \\
\text { лювати їх у вигляді наукової публікації, виступу чи твору укра- } \\
\text { їнською та/або іноземною мовами. }\end{array}$ \\
\hline & $\begin{array}{l}\text { Спеціалізовано-професійні компетентності } \\
\text { СК2. } \\
\text { Здатність застосовувати знання фундаментальних основ, сучас- } \\
\text { них досліджень, проблем і тенденцій із спеціальності Технології } \\
\text { медичної діагностики та лікування в галузі Охорони здоров’я } \\
\text { в комплексному аналізі явищ і процесів, що виникають в Україні } \\
\text { та в світі в цілому. }\end{array}$ \\
\hline & $\begin{array}{l}\text { CK3. } \\
\text { Здатність відокремлювати структурні елементи, що складають } \\
\text { теоретичну та емпіричну основу системи знань зі спеціальності } \\
\text { Технології медичної діагностики та лікування. }\end{array}$ \\
\hline & $\begin{array}{l}\text { CK4. } \\
\text { Здатність формулювати план, висновок протоколу та обгрун- } \\
\text { товувати рекомендації; визначати покази та протипоказання } \\
\text { для проведення досліджень шляхом співставлення зі стандарта- } \\
\text { ми, використовуючи попередні дані анамнезу пацієнта, на основі }\end{array}$ \\
\hline
\end{tabular}


провідного клінічного симптому або синдрому, використовуючи знання про людину, її органи та системи, дотримуючись відповідних етичних та юридичних норм, шляхом прийняття обгрунтованого рішення поставити найбільш вірогідний або синдромний діагноз захворювання.

\section{CK5.}

Здатність проводити дослідження на різноманітних типах сучасної ядерно-медичної апаратури: гамма-камерах, однофотонних емісійних комп’ютерних томографах, позитронних емісійних томографах, комбінованих (гібридних) апаратах; обирати відповідний радіофармацевтичний препарат для конкретної методики, розраховувати активність для введення пацієнту та визначати ефективну дозу його опромінення.

\section{CK6.}

Здатність до розроблення та/або застосування медичних інформаційних систем, технології «Big Data», впровадження електронної документації, електронної історії хвороби тощо.

\section{CK7.}

Здатність здійснювати променеву терапію сучасними методами опромінювання пухлин за допомогою радіотерапевтичної апаратури різних типів (гамма-дистанційні установки, лінійні прискорювачі, рентгентерапевтичні апарати, апарати для проведення брахітерапії). Здатність обрати оптимальну поглинуту дозу в патологічному вогнищі та оточуючих життєво важливих структурах.

CK8.

Здатність рекомендувати необхідні лабораторні дослідження для оцінювання ефективності лікування пацієнтів на інфекційні та неінфекційні захворювання, стану жінки та плоду під час вагітності, стану організму пацієнта при реабілітаційних заходах; проведення заходів щодо попередження розповсюдження інфекційних та паразитарних захворювань шляхом дотримання санітарних норм і правил при роботі з біологічними матеріалами.

\section{CK9.}

Здатність використовувати чинне законодавство та нормативні документи, що регламентують діяльність органів управління і закладів охорони здоров’я України, а також документацію для якості та ефективності роботи, зокрема клініко-діагностичних лабораторій.

\section{CK10.}

Здатність використовувати знання організаційної структури, управлінської та економічної діяльності закладів охорони здоров’я України, зокрема клініко-діагностичних лабораторій, аналізувати показники роботи їх структурних підрозділів, проводити оцінювання ефективності сучасних медико-організаційних і соціально-економічних технологій при наданні медичних послуг пацієнтам. 


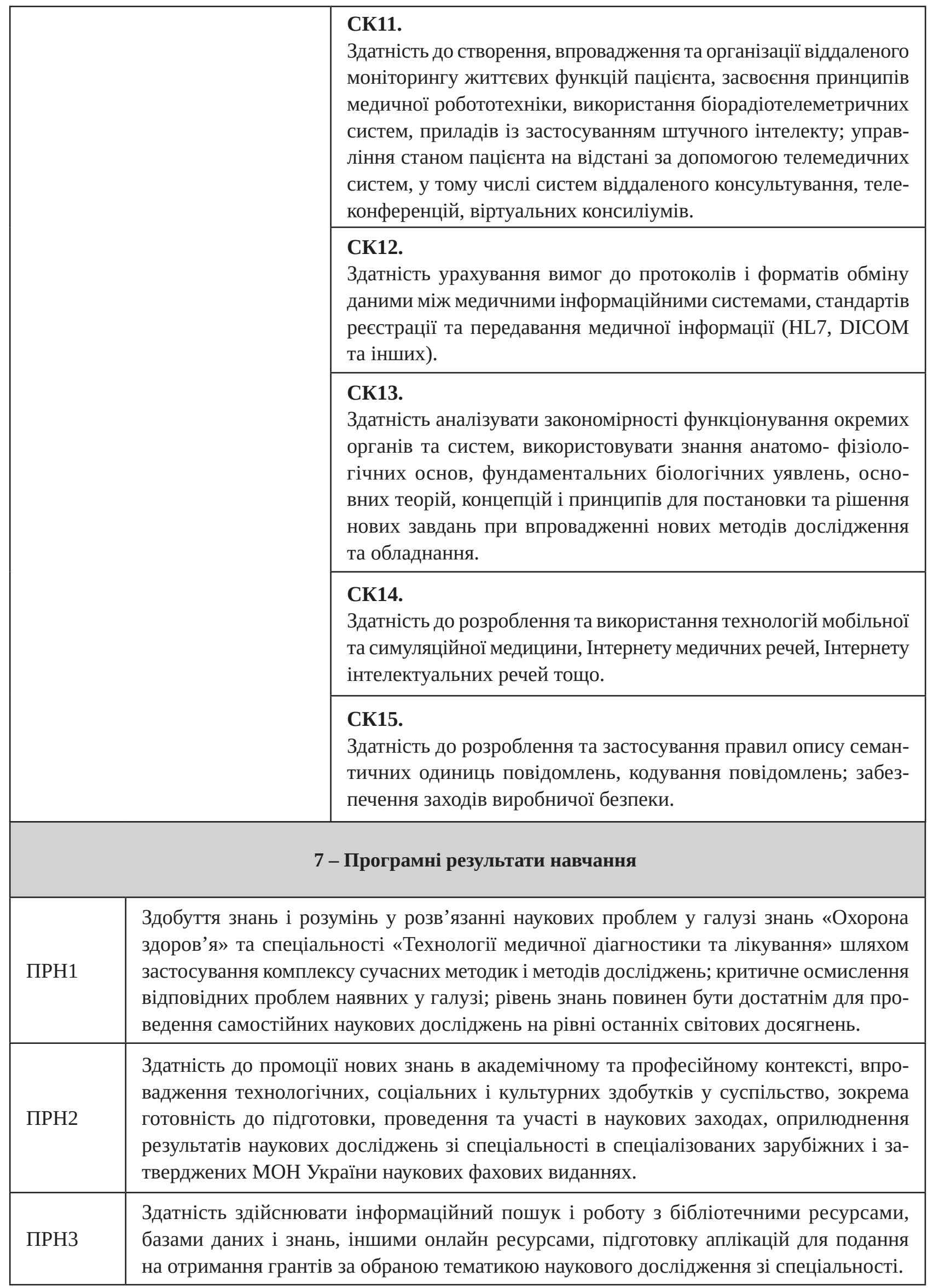




\begin{tabular}{|c|c|}
\hline ПРН4 & $\begin{array}{l}\text { Здатність розроблення наукового проєкту відповідно до завдань дисертаційного дослі- } \\
\text { дження; складання пропозицій із фінансування наукових досліджень у галузі. }\end{array}$ \\
\hline ПРН5 & $\begin{array}{l}\text { Здатність здійснювати оброблення та інтерпретацію отриманих експериментальних } \\
\text { і емпіричних даних, використовувати сучасні математичні та статистичні методи при об- } \\
\text { робленні даних наукових досліджень. }\end{array}$ \\
\hline ПРН6 & $\begin{array}{l}\text { Здатність застосовувати філософські знання у теорії та практиці; здатність до абстрак- } \\
\text { тного мислення, аналізу та синтезу, до здійснення пошукової (евристичної) діяльності, } \\
\text { дослідження пріоритетних напрямів розвитку спеціальності, організації та проведення } \\
\text { наукових досліджень із сучасних проблем. }\end{array}$ \\
\hline ПРН7 & $\begin{array}{l}\text { Здатність підготувати та успішно захистити дисертаційну роботу зі спеціальності } \\
\text { Технології медичної діагностики та лікування на основі власних досліджень, а також } \\
\text { використовувати (та визнати) результати роботи інших членів наукової групи. }\end{array}$ \\
\hline ПРН8 & $\begin{array}{l}\text { Здатність до усвідомлення мовних норм, що склалися історично в фонетиці, лексиці, } \\
\text { граматиці, орфоепії, семантиці, стилістиці та адекватне їх застосування в предметній } \\
\text { області галузі та спеціальності в процесі використання державної чи іноземної мови. }\end{array}$ \\
\hline ПРН9 & $\begin{array}{l}\text { Здатність до проведення вербального та невербального спілкування, спостереження, } \\
\text { вислуховування, постановки запитань, здатність вести співбесіду з різними групами } \\
\text { співрозмовників, проведення та участь у зборах. }\end{array}$ \\
\hline ПРН10 & $\begin{array}{l}\text { Здатність адекватно та доречно практично користуватися мовою в конкретних ситуаціях } \\
\text { (висловлювати свої думки, бажання, наміри, прохання тощо), встановлювати та під- } \\
\text { тримувати необхідні контакти з іншими людьми, використовувати для цього як мовні, } \\
\text { так і позамовні та інтонаційні засоби виразності мовлення. }\end{array}$ \\
\hline ПРН11 & $\begin{array}{l}\text { Формування системи знань зі спеціальності, використовуючи унікальні дані, обгрун- } \\
\text { товані рішення, нові інтерпретації, інноваційні методи, за допомогою оригінальних } \\
\text { досліджень і прогресивних учень. }\end{array}$ \\
\hline ПРН12 & $\begin{array}{l}\text { Уміння на теоретичному рівні генерувати ідеї, гіпотези наукового дослідження, роз- } \\
\text { робляти доказову базу, визначати закономірності; розуміти та будувати міждисциплінарні } \\
\text { зв'язки між природничими та гуманітарними науками. }\end{array}$ \\
\hline ПРН13 & $\begin{array}{l}\text { Здатність слідувати етико-правовим нормам і моральним цінностям, принципам біо- } \\
\text { етики у професійній діяльності, дотримуватись принципів академічної доброчесності. }\end{array}$ \\
\hline ПРН14 & $\begin{array}{l}\text { Уміння використовувати сучасні дані, накопичені в результаті наукових досліджень, } \\
\text { застосовувати знання, отримані та відібрані в ході експериментальних досліджень } \\
\text { і практичної діяльності зі спеціальності, для визначення ефективності, систематизації, } \\
\text { узагальнення та пояснення. }\end{array}$ \\
\hline ПРН15 & $\begin{array}{l}\text { Здатність до розроблення, організації та впровадження профілактичних і реабілітацій- } \\
\text { них стратегій на основі особистих досліджень та авторських методик при створенні } \\
\text { та реалізації індивідуального плану діагностики та лікування з метою покращення } \\
\text { здоров’я, функціональних можливостей, адаптації до оточуючих умов, підвищення } \\
\text { рівня здоров’я населення. }\end{array}$ \\
\hline ПРН16 & $\begin{array}{l}\text { Знання та навики до використання пристроїв, приладів та обладнання для проведення } \\
\text { діагностично-лікувальних і реабілітаційних заходів; пристроїв та обладнання для кон- } \\
\text { тролю основних життєвих показників пацієнта. }\end{array}$ \\
\hline ПРН17 & $\begin{array}{l}\text { Здатність спілкуватися з нефахівцями своєї галузі (робота в мультидисциплінарній } \\
\text { команді). Вміння спілкування з людьми з різними психологічними якостями, різного } \\
\text { віку, рівня освіти, соціальної та професійної приналежності. }\end{array}$ \\
\hline
\end{tabular}




\begin{tabular}{|c|c|c|}
\hline ПРН18 & \multicolumn{2}{|c|}{$\begin{array}{l}\text { Здатність до розроблення діагностичних стратегій при створенні та реалізації індиві- } \\
\text { дуального плану зі спеціальності з метою покращення рівня здоров’я, функціональних } \\
\text { можливостей пацієнта та населення. }\end{array}$} \\
\hline ПРН19 & \multicolumn{2}{|c|}{$\begin{array}{l}\text { Здатність до аналізу, співставлення, порівняння варіантів розвитку в галузі знань } \\
\text { «Охорона здоров’я» та спеціальності «Технології медичної діагностики та лікування», } \\
\text { розв’язання у контексті викликів XXI ст. }\end{array}$} \\
\hline \multicolumn{3}{|c|}{8 - Ресурсне забезпечення реалізації програми } \\
\hline \multicolumn{2}{|c|}{$\begin{array}{l}\text { Специфічні характеристики } \\
\text { кадрового забезпечення }\end{array}$} & $\begin{array}{l}\text { Кадрове забезпечення освітнього процесу відповідає Ліцензійним } \\
\text { умовам провадження освітньої діяльності закладу освіти у сфері } \\
\text { вищої освіти. Викладання навчальних дисциплін здійснюється } \\
\text { науково-педагогічними працівниками } 3 \text { науковим ступенем } \\
\text { за профілем спеціальності. }\end{array}$ \\
\hline \multicolumn{2}{|c|}{$\begin{array}{l}\text { Специфічні характеристики } \\
\text { матеріально-технічного } \\
\text { забезпечення }\end{array}$} & $\begin{array}{l}\text { Навчальні лабораторії кафедр, задіяних у здійсненні освітньої } \\
\text { діяльності за ОНП «Технології медичної діагностики та лікуван- } \\
\text { ня», забезпечені необхідним сучасним обладнанням; науковий } \\
\text { навчально-методичний центр дистанційної освіти, центр симу- } \\
\text { ляційних методів навчання з кабінетом лабораторної медицини, } \\
\text { науково-дослідний центр, клініка репродуктивних технологій, } \\
\text { комп’ютерні класи, наукова бібліотека; понад } 200 \text { баз, серед яких } \\
18 \text { науково-дослідні інститути НАМН України та } 4 \text { установи } \\
\text { НАН України, заклади охорони здоров’я різного підпорядкування } \\
\text { - партнери різної форми власності, з якими укладено відповідні } \\
\text { договори, створюють умови для ефективної та якісної практичної } \\
\text { підготовки здобувачів освіти та виконання наукових досліджень. }\end{array}$ \\
\hline \multicolumn{2}{|c|}{$\begin{array}{l}\text { Специфічні характеристики } \\
\text { інформаційного та навчально- } \\
\text { методичного забезпечення }\end{array}$} & $\begin{array}{l}\text { Офіційний веб-сайт НУОЗ України імені П. Л. Шупика: } \\
\text { https://nuozu.edu.ua/. }\end{array}$ \\
\hline \multicolumn{3}{|r|}{9 - Академічна мобільність } \\
\hline \multicolumn{2}{|c|}{$\begin{array}{l}\text { Національна } \\
\text { кредитна мобільність }\end{array}$} & $\begin{array}{l}\text { Забезпечується двосторонніми договорами (угодами) між НУОЗ } \\
\text { України імені П. Л. Шупика та ЗВО України / установами НАН } \\
\text { України та НАМН України. }\end{array}$ \\
\hline \multicolumn{2}{|c|}{$\begin{array}{l}\text { Міжнародна } \\
\text { кредитна мобільність }\end{array}$} & $\begin{array}{l}\text { Забезпечується двосторонніми договорами (угодами) між НУОЗ } \\
\text { України імені П. Л. Шупика та ЗВО країн-партнерів. }\end{array}$ \\
\hline \multicolumn{2}{|c|}{$\begin{array}{l}\text { Навчання іноземних } \\
\text { здобувачів вищої освіти }\end{array}$} & $\begin{array}{l}\text { Навчання іноземних здобувачів вищої освіти здійснюється } \\
\text { на загальних умовах українською. }\end{array}$ \\
\hline
\end{tabular}




\section{2. ПЕРЕЛІК КОМПОНЕНТ ОСВІТНЬОЇ ПРОГРАМИ ТА ЇХ ЛОГІЧНА ПОСЛІДОВНІСТЬ}

\section{1. Розподіл змісту освітньо-наукової програми підготовки доктора філософії}

\begin{tabular}{|c|c|}
\hline Зміст освітньо-наукової програми & $\begin{array}{c}\text { Академічних годин/кредитів } \\
\text { ЄКТС }\end{array}$ \\
\hline $\begin{array}{l}\text { Загальний навчальний час підготовки } \\
\text { (академічних годин/кредитів ЄКТС) } \\
\text { для докторів філософії за спеціальністю } 224 \\
\text { «Технології медичної діагностики та лікування» }\end{array}$ & 60 кредитів \\
\hline $\begin{array}{l}\text { Оволодіння загальнонауковими (філософськими) } \\
\text { компетентностями }\end{array}$ & 5 кредитів \\
\hline $\begin{array}{ll}\text { Набуття універсальних навиків дослідника: } \\
\text { - } \quad \text { усної і письмової презентації результатів власного } \\
\text { наукового дослідження українською мовою та реєстрації } \\
\text { прав інтелектуальної власності } \\
\text { - } \quad \text { застосування сучасних інформаційних технологій } \\
\text { у науковій діяльності } \\
\text { - }\end{array}$ & $\begin{array}{c}14 \text { кредитів } \\
2 \text { кредити } \\
\\
5 \text { кредитів } \\
4 \text { кредити } \\
3 \text { кредити }\end{array}$ \\
\hline Здобуття мовних компетентностей & 8 кредитів \\
\hline $\begin{array}{l}\text { Здобуття глибинних знань зі спеціальності, за якою здобувач } \\
\text { вищої освіти проводить дослідження } \\
\text { Асистентська педагогічна практика за спеціальністю }\end{array}$ & $\begin{array}{l}9 \text { кредитів } \\
3 \text { кредити }\end{array}$ \\
\hline $\begin{array}{l}\text { Дисципліни за вибором } \\
\text { (не менше } 25 \text { \% загальної кількості кредитів ЄКТС) }\end{array}$ & 21 кредит \\
\hline
\end{tabular}




\section{2. Перелік компонент освітньо-наукової програми}

\begin{tabular}{|c|c|c|c|}
\hline $\begin{array}{l}\text { Код } \\
\text { н/д }\end{array}$ & Компоненти освітньої-наукової програми & $\begin{array}{c}\text { Кількість } \\
\text { кредитів }\end{array}$ & $\begin{array}{l}\text { Форма } \\
\text { підсумкового } \\
\text { контролю }\end{array}$ \\
\hline 1 & 2 & 3 & 4 \\
\hline \multicolumn{2}{|c|}{ Загальний обсяг освітньо-наукової програми } & 60 & \\
\hline \multicolumn{4}{|c|}{ Обов’язкові компоненти ОНП } \\
\hline \multicolumn{2}{|c|}{ Загальний обсяг обов’язкових компонент } & 39 & \\
\hline \multicolumn{4}{|c|}{$\begin{array}{c}\text { Оволодіння загальнонауковими (філософськими) компетентностями, спрямованими на формуван- } \\
\text { ня системного наукового світогляду, професійної етики та загального культурного кругозору }\end{array}$} \\
\hline OK1 & $\begin{array}{l}\text { Філософія, сучасна методологія наукових досліджень } \\
\text { і біоетика }\end{array}$ & 5 & залік \\
\hline \multicolumn{4}{|c|}{ Набуття універсальних навиків дослідника } \\
\hline OK2 & $\begin{array}{l}\text { Управління науковими проєктами. } \\
\text { Фінансування наукових досліджень }\end{array}$ & 3 & залік \\
\hline OK3 & $\begin{array}{l}\text { Презентація результатів наукових досліджень. Реєстрація } \\
\text { та захист прав інтелектуальної власності }\end{array}$ & 2 & залік \\
\hline OK4 & $\begin{array}{l}\text { Сучасні інформаційні технології } \\
\text { у науковій діяльності та біостатистика }\end{array}$ & 5 & залік \\
\hline OK5 & $\begin{array}{l}\text { Методологія та організація педагогічного процесу, } \\
\text { проведення навчальних занять і асистентської педагогічної } \\
\text { практики }\end{array}$ & 4 & залік \\
\hline \multicolumn{4}{|c|}{$\begin{array}{c}\text { Набуття мовних компетентностей, достатніх для представлення та обговорення результатів } \\
\text { своєї наукової роботи іноземною мовою в усній і письмовій формі, а також для повного розуміння } \\
\text { іншомовних наукових програм }\end{array}$} \\
\hline OK6 & Іноземна мова Upper Intermediate & 8 & залік \\
\hline \multicolumn{4}{|c|}{ Здобуття глибинних знань зі спеціальності, за якою здобувач проводить дослідження } \\
\hline OK7 & $\begin{array}{l}\text { Курс професійної та практичної підготовки } \\
\text { за спеціальністю }\end{array}$ & 9 & залік \\
\hline OK8 & Асистентська педагогічна практика за спеціальністю & 3 & залік \\
\hline
\end{tabular}


Вибіркові компоненти ОНП

\begin{tabular}{|c|c|c|c|}
\hline \multicolumn{2}{|c|}{ Загальний обсяг вибіркових компонент } & 21 & \\
\hline 1 & 2 & 3 & 4 \\
\hline
\end{tabular}

Вибіркові дисципліни, спрямовані на набуття загальних компетентностей*

\begin{tabular}{|c|c|c|c|}
\hline BK9 & Доказова медицина & 3 & залік \\
\hline BK10 & Логіка наукового дослідження та сучасна філософія науки & 3 & залік \\
\hline BK11 & Методологічні та етико-правові засади біомедичних досліджень & 3 & залік \\
\hline BK12 & Математичне моделювання в охороні здоров’я та біології & 3 & залік \\
\hline BK13 & Інформаційні технології пошуку та структуризації інформації & 3 & залік \\
\hline BK14 & $\begin{array}{l}\text { Актуальні питання медичного та фармацевтичного права. Правове забез- } \\
\text { печення досліджень у галузі охорони здоров’я та галузі біології }\end{array}$ & 3 & залік \\
\hline BK15 & Технології наукової творчості. Основи академічного письма та риторики & 3 & залік \\
\hline BK16 & $\begin{array}{l}\text { Морально-етичні та соціокультурні виміри природничих наук } \\
\text { і біотехнологій }\end{array}$ & 3 & залік \\
\hline BK17 & Системна біомедицина & 3 & залік \\
\hline BK18 & Психологічні механізми науково-дослідної діяльності & 3 & залік \\
\hline BK19 & $\begin{array}{l}\text { Психологічні та правові аспекти конфліктології (у галузі охорони здоров’я } \\
\text { та галузі біологія) }\end{array}$ & 3 & залік \\
\hline \multicolumn{4}{|c|}{ Вибіркові дисципліни, спрямовані на набуття спеціальних компетентностейж* } \\
\hline BK20 & $\begin{array}{l}\text { Вибіркові навчальні дисципліни, а також цикли тематичного удосконалення, } \\
\text { стажування, спеціалізації та інші форми неформальної та інформальної освіти } \\
\text { за вибором здобувача вищої освіти (спрямовані на формування спеціальних } \\
\text { компетентностей) }\end{array}$ & 3-15 & залік \\
\hline
\end{tabular}

Примітки: * - здобувач вищої освіти обирає дві дисципліни з кожного тематичного напряму; ** - здобувач вищої освіти обирає одну дисципліну з переліку, представленому на офіційному веб-сайті університету. 


\section{3. СТРУКТУРНО-ЛОГІЧНА СХЕМА ПІДГОТОВКИ ДОКТОРІВ ФІЛОСОФІї}

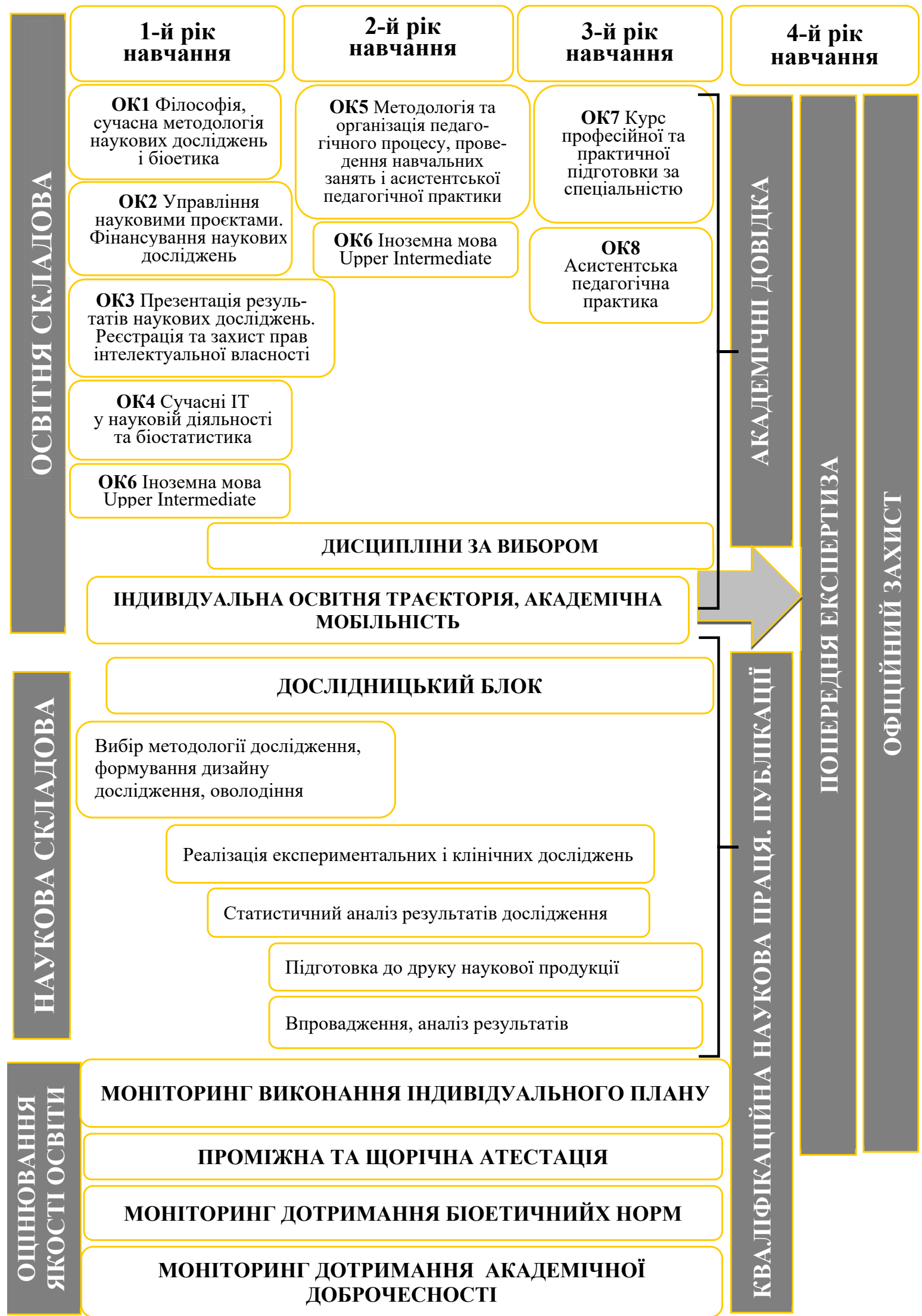




\section{3. ФОРМА АТЕСТАЦІЇ ЗДОБУВАЧІВ ВИЩОЇ ОСВІТИ}

Атестація осіб, які здобувають ступінь доктора філософії, здійснюється постійно діючою або разовою спеціалізованою вченою радою, акредитованою Національним агентством із забезпечення якості вищої освіти, на підставі публічного захисту наукових досягнень у формі кваліфікаційної наукової праці (дисертаційної роботи).

Кваліфікаційна наукова праця на здобуття ступеня доктора філософії є самостійним розгорнутим дослідженням, що пропонує розв’язання актуального наукового завдання в галузі Охорони здоров’я або на її межі та сумісних галузей, результати якого становлять оригінальний внесок у загальну суму знань із Технологій медичної діагностики та лікування й оприлюднені у відповідних публікаціях.
Обов'язковою умовою допуску до захисту $€$ успішне виконання здобувачем його індивідуального навчального плану.

Здобувач ступеня доктора філософії має право на вибір спеціалізованої вченої ради.

Кваліфікаційні наукові праці осіб, які здобувають ступінь доктора філософії, а також відгуки опонентів оприлюднюються на офіційному веб-сайті НУОЗ України імені П. Л. Шупика відповідно до чинного законодавства.

Підсумкова атестація здобувачів вищої освіти, які повністю виконали програму підготовки доктора філософії за спеціальністю 224 «Технології медичної діагностики та лікування», завершується присудженням наукового ступеня доктора філософії за спеціальністю 224 «Технології медичної діагностики та лікування» галузі знань 22 «Охорона здоров’я» $з$ врученням диплому встановленого зразка.

Захист дисертаційної роботи передбачає перевірку програмних результатів навчання:

Здатність особи розв’язувати комплексні проблеми в галузі професійної та/або дослідницько-інноваційної діяльності, що передбачає глибоке переосмислення наявних і створення нових цілісних знань та/або професійної практики

\begin{tabular}{|c|c|}
\hline Знання. & \\
\hline $\begin{array}{l}\text { Концептуальні та методологічні знання в галузі чи на межі } \\
\text { галузей знань або професійної діяльності. }\end{array}$ & ПРН15 \\
\hline Уміння/навики. & \\
\hline $\begin{array}{l}\text { Спеціалізовані уміння/навики і методи, необхідні для } \\
\text { розв’язання значущих проблем у сфері професійної діяльності, } \\
\text { науки та/або інновацій, розширення та переоцінки вже існуючих } \\
\text { знань і професійної практики. }\end{array}$ & ПРН1; ПРН5 \\
\hline $\begin{array}{l}\text { Започаткування, планування, реалізація та коригування } \\
\text { послідовного процесу грунтовного наукового дослідження } \\
\text { з дотриманням належної академічної доброчесності. }\end{array}$ & ПРНЗ; ПРН4 \\
\hline $\begin{array}{l}\text { Критичний аналіз, оцінювання та синтез нових і комплексних } \\
\text { ідей. }\end{array}$ & ПРН1 \\
\hline Комунікація. & \\
\hline $\begin{array}{l}\text { Вільне спілкування з питань, що стосуються сфери наукових } \\
\text { та експертних знань, з колегами, широкою науковою } \\
\text { спільнотою, суспільством у цілому. }\end{array}$ & ПРН2 \\
\hline $\begin{array}{l}\text { Використання академічної української та іноземної мови } \\
\text { у професійній діяльності та дослідженнях. }\end{array}$ & $\begin{array}{l}\text { ПРН2; ПРН8; ПРН9; ПРН10; } \\
\text { ПРН12 }\end{array}$ \\
\hline
\end{tabular}




\begin{tabular}{|l|l|}
\hline Відповідальність і автономія. & \\
\hline Демонстрація значної авторитетності, інноваційність, \\
$\begin{array}{l}\text { високий ступінь самостійності, академічна та професійна } \\
\text { доброчесність, послідовна відданість розвитку нових ідей } \\
\text { або процесів у передових контекстах професійної та наукової } \\
\text { діяльності. }\end{array}$ & ПРН6; ПРН7; ПРН11; ПРН14; \\
\hline $\begin{array}{l}\text { Здатність до безперервного саморозвитку та } \\
\text { самовдосконалення. }\end{array}$ & ПРН13 \\
\hline
\end{tabular}

\section{Система внутрішнього забезпечення якості вищої освіти}

Система внутрішнього забезпечення якості вищої освіти НУОЗ України імені П. Л. Шупика складається з процедур і заходів, передбачених Законами України «Про освіту» та «Про вищу освіту».

\section{4. МАТРИЦЯ ВІДПОВІДНОСТІ ПРОГРАМНИХ КОМПЕТЕНТНОСТЕЙ КОМПОНЕНТАМ ОСВІТНЬОЇ ПРОГРАМИ}

\begin{tabular}{|c|c|c|c|c|c|c|c|c|c|c|c|c|c|c|c|c|c|c|c|c|}
\hline & 룽 & $\frac{N}{0}$ & $\frac{n}{0}$ & $\frac{ \pm}{0}$ & $\frac{1}{0}$ & 菊 & $\frac{1}{0}$ & $\begin{array}{l}\infty \\
\frac{1}{0}\end{array}$ & $\frac{\sigma}{n}$ & $\frac{}{\stackrel{1}{a}}$ & $\underset{7}{\nexists}$ & $\frac{\mathcal{Z}}{\mathfrak{y}}$ & $\frac{m}{\ddot{n}}$ & $\frac{ \pm}{ \pm}$ & $\frac{10}{=}$ & $\frac{0}{\frac{1}{n}}$ & $\frac{\nabla}{2}$ & $\frac{\infty}{=}$ & $\frac{\sigma}{2}$ & 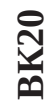 \\
\hline 3K1 & + & + & + & + & & + & + & + & + & + & + & + & + & + & + & + & + & & & + \\
\hline $3 \mathrm{~K} 2$ & & + & & + & + & + & + & + & & & & & & & & & + & + & + & + \\
\hline ЗКЗ & + & + & & + & + & + & + & + & & + & + & & & & & & + & + & + & \\
\hline 3K4 & & + & + & + & + & & + & & & & & & + & & + & + & + & + & + & \\
\hline 3K5 & & & + & + & + & & & & & & & & & + & + & + & & + & + & \\
\hline 3K6 & + & + & & & & & & & + & + & + & + & & & & & + & & & \\
\hline 3K7 & & & & & + & + & & + & & & & & & & & + & & + & & \\
\hline ЗК8 & + & & & & + & & + & & + & + & + & + & & + & & & & + & + & + \\
\hline ЗК9 & + & & & & & & + & & & & + & + & + & & & & + & & & \\
\hline CK1 & + & + & + & + & & + & + & & & + & + & + & + & + & + & + & + & + & & + \\
\hline CK2 & + & + & & & & + & + & + & & + & & & & & + & & & & & + \\
\hline CK3 & + & & & & + & + & & + & + & & & + & & & + & & & & & + \\
\hline CK4 & + & & & & & + & + & + & & & + & + & + & + & + & + & + & & & + \\
\hline CK5 & & & & & & & + & + & & & & & + & & + & & + & & & + \\
\hline CK6 & & & + & & & & + & & & & & & + & + & + & + & & & & + \\
\hline CK7 & & & + & & & & + & + & & & & & + & + & & & & & & + \\
\hline
\end{tabular}




\begin{tabular}{|l|l|l|l|l|l|l|l|l|l|l|l|l|l|l|l|l|l|l|l|l|}
\hline CK8 & & + & + & & & + & & & & & & + & & & & + & & & + \\
\hline CK9 & & + & & & & + & + & & & & & + & + & & + & + & & & + \\
\hline CK10 & & + & & & & + & + & & & & & & & + & + & & & & + \\
\hline CK11 & & + & & & + & & + & + & + & & + & & & & + & & & & + \\
\hline CK12 & & + & & + & & + & + & & & & & + & & & + & & & & + \\
\hline CK13 & & & + & & & + & & & & & & & & & & + & & & + \\
\hline CK14 & & + & & & & + & + & & & & & & & + & & + & & & + \\
\hline
\end{tabular}

5. МАТРИЦЯ ЗАБЕЗПЕЧЕННЯ ПРОГРАМНИХ РЕЗУЛЬТАТІВ НАВЧАННЯ ВІДПОВІДНИМИ КОМПОНЕНТАМИ ОСВІТНЬОЇ ПРОГРАМИ

\begin{tabular}{|c|c|c|c|c|c|c|c|c|c|c|c|c|c|c|c|c|c|c|c|c|}
\hline & 晃 & $\frac{\mathfrak{Z}}{0}$ & है & 药 & 资 & 艺 & 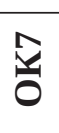 & $\begin{array}{l}\infty \\
\mathfrak{c}\end{array}$ & 党 &  & $\vec{F}$ & $\underset{\mathfrak{z}}{\mathfrak{y}}$ & $\underset{m}{\stackrel{n}{n}}$ & 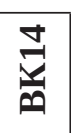 & 足 & 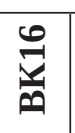 & 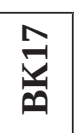 & 舀 & $\underset{\theta}{g}$ & 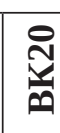 \\
\hline ПРН1 & + & + & + & + & & + & + & & + & + & + & & + & + & + & + & + & & & + \\
\hline ПРН2 & + & + & & + & + & & + & + & & + & & & & + & & + & + & + & + & \\
\hline ПРНЗ & & & + & + & & + & + & & & & & + & + & + & & & + & & & + \\
\hline ПРН4 & & & + & + & & & + & & & & & + & + & & & & & & & \\
\hline ПРН5 & & & + & + & & & + & & & & & + & + & + & & & & & & + \\
\hline ПРН6 & + & & + & & & + & + & & + & & + & + & & + & + & & & & & + \\
\hline ПРН7 & + & + & + & + & & + & + & & & + & & & & + & & + & + & + & & + \\
\hline ПРН8 & & + & & & & + & + & + & & & & & & & & & & & & + \\
\hline ПРН9 & & + & & & + & & + & + & & & & & & & & & & + & + & \\
\hline ПРН10 & & & & + & + & + & + & + & & + & & & & + & & & & + & + & \\
\hline ПРН11 & & & & + & + & & + & + & & & & & & + & + & & & & & + \\
\hline ПРРН12 & + & & & & & & + & + & + & & + & & & + & + & & & & & \\
\hline ПРН13 & + & & & & & & + & & & & & + & & & & & & & & + \\
\hline ПРРН14 & & + & & & + & + & & + & + & & + & + & + & & + & & & & & + \\
\hline ПРН15 & & & & & & & + & + & & + & & & & + & + & + & & & & + \\
\hline ПРН16 & + & & & & + & & + & + & & & & + & + & + & + & & & + & + & + \\
\hline ПРН17 & & + & & & + & + & & + & & & & & + & & & & + & + & + & + \\
\hline ПРН18 & + & & & & & & + & + & + & & & & & & + & + & & & & + \\
\hline ПРН19 & + & + & + & & & & + & & + & & & & & & + & & & & & + \\
\hline
\end{tabular}

